\title{
GEOMORPHOLOGY OF THE PACAÁS NOVOS RANGE, SOUTHWESTERN AMAZONIA, BRAZIL: ONE EXAMPLE ON THE IMPORTANCE OF GEOMORPHOLOGICAL EVIDENCES TO THE RECONSTRUCTION OF QUATERNARY PALEOENVIRONMENTAL SCENARIOS IN AMAZONIA
}

\section{EDGARDO M. LATRUBESSE ${ }^{1}$, ANTONIO ROSSI ${ }^{2}$ AND ELENA FRANZINELLI $^{3}$}

\begin{abstract}
The geomorphology of the Pacaás Novos Range was surveyed. The study area is situated in the State of Rondonia, southwestern Amazonia, near the Brazil - Bolivia border. The range is formed by sedimentary Precambrian rocks and the piedmont area by Precambrian crystalline rocks of the Guaporé Shield. The occurrence of a thick saprolite mantle, detrital talus, pediments, duricrust formation, dissection and alluvial fans provide strong evidence that the morphogenetic systems changed drastically in this part of Amazonia during the Quaternary.
\end{abstract}

Keywords: south-western Amazonia, Quaternary, geomorphology, palaeoclimates

INTRODUCTION Geomorphological evidence is currently used in the tropics for the interpretation of paleoclimatic fluctuations and to evince variations in the Quaternary environment. A fair amount of the present information on the Quaternary evolution of humid tropical African and Asiatic rainforests is provided by geomorphological evidences (De Ploey 1964; data review in Thomas 1994, Kadomura and Hori 1990, Thomas and Thorpe 1985, 1992, Runge 1992, 1995, and many others). On the contrary the Amazon is characterized by the lack of such information. During the last 30 years, studies concerning the geomorphology of the Brazilian Amazon Basin focused principally on some aspects of fluvial geomorphology, soil development and weathering (Ab Saber 1967, 1982, Chauveletal. 1987, Iriondo 1982, Iriondo and Latrubesse 1994, Journaux 1975, Costa 1991, Klammer 1971, 1984, Lucas et al 1987, 1988, Meis 1968, Mertes et al 1996, Tricart 1977, 1885, and others). Data on the Quaternary are provided basically by the study of fluvial and lacustrine deposits, palinology and vertebrate paleontology (among others, Absy et al. 1991, Latrubesse and Franzinelli 1998, Latrubesse and Ramonell 1994, Latrubesse and Rancy 1998, Rancy 1993, Rasanenera/. 1992, Van der Hammen and Absy 1994)

Our aim here is to evaluate the potential of the geomorphological record from some areas of Brazilian Amazonia and to determine paleoenvironmental indicators. We present results from the Pacaás Novos Range area, Rondonia State, Brazil.

This region is situated on the Brazil - Bolivia border, to the east of

the Madeira-Mamore River $\left(65^{\circ} 20^{\prime} \mathrm{W} ; 10^{\circ} 44^{\prime} \mathrm{S}\right)$ (Fig.l) and is Figure 1 - Location map indicating the study area covered by tropical rainforest. The climate of this area is humid tropical with a dry season of three months duration, average temperature of $24^{\circ} \mathrm{C}$, and rainfall between 2000 and $2250 \mathrm{~mm} /$ year (Nimer 1989).

METHODS Analysis of radar mosaics (SLAR), LANDSAT images and aerial photographs, before and during the fieldwork, aided in the identification of the geomorphologic features. Intensive fieldwork was carried out in 1996 and in 1997. Slope and morphometric measurements of landforms were performed in the field by theodolite.

Grain size of the sediments was obtained during the laboratory stage. Mineralogical determinations were obtained using X-ray diffraction and petrographic microscopy. X-ray diffraction was done on the total sedimentary fraction after triturating. Geochemical determinations were performed by X-ray fluorescence. Absolute dating was performed by thermoluminescence on the quartz particles of the sediments.

GEOLOGICAL BACKGROUND The main geological unit outcropping in the area is the Guapore Shield, which is composed of igneous and metamorphic rocks of the Xingu Complex, Lower Precambrian in age. This unit is defined in the area as a Regional Surface of Planation of Rondonia and identified as Level II (less than $300-\mathrm{m}$. a.s.l). The Pacaás Novos Formation rests on the rocks of the crystalline basement in the area of the northern piedmont (Fig. 2), where it is possible to observe the contact between the range escarpment formed by the sedimentary rocks of the Pacaás Novos
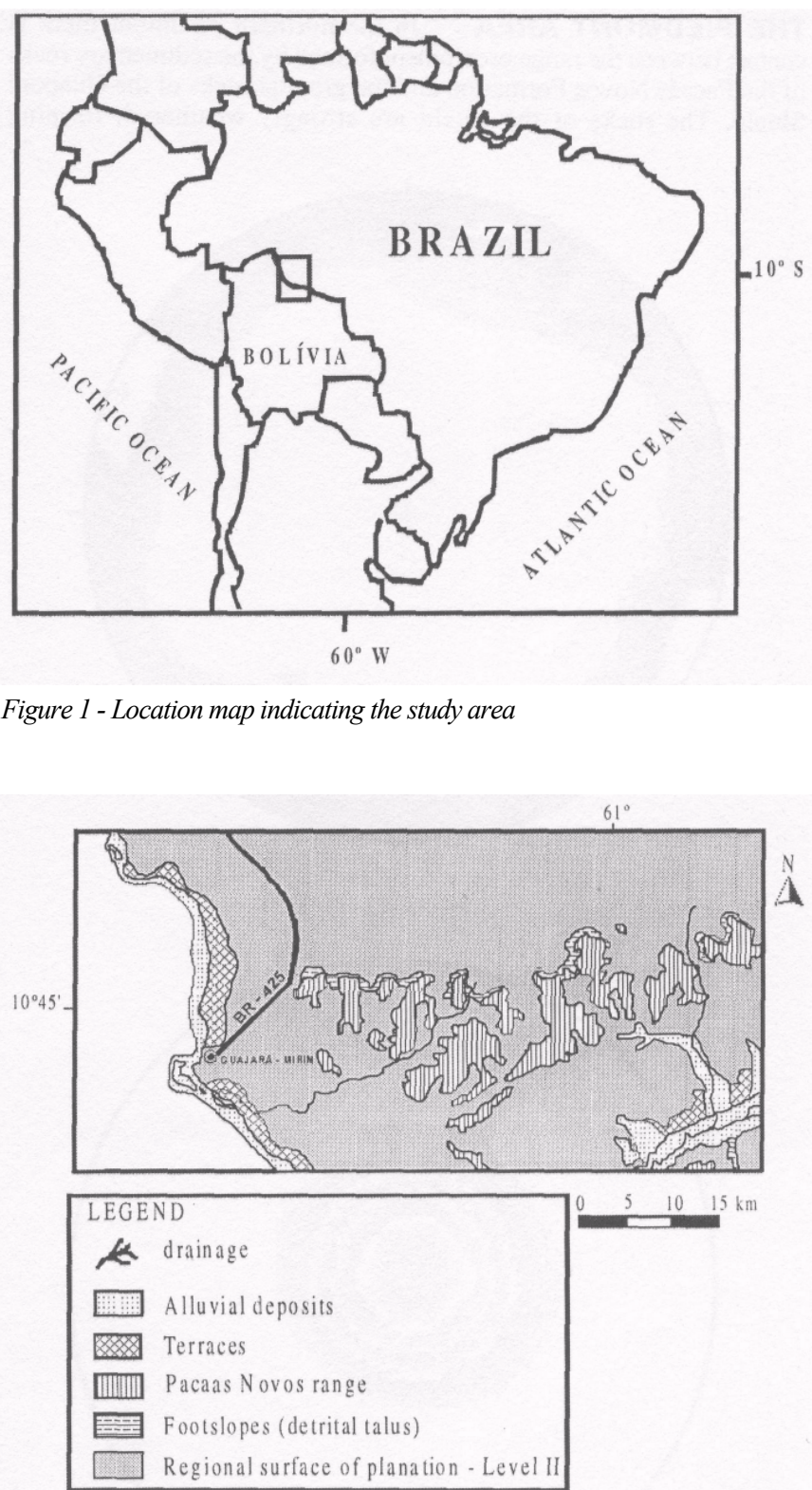

1 - Universidade Federal de Goias - IESA - Campus Samambaia, Goiania, GO, Brasil. E-mail: latrubes@virtualhouse.com.br

2 - Universita degli Studi di Modena, Dipartamento di Scienze della Terra, Largo santa Eufemia 19, Modena, Italia. E-mail antoross@unimo.it

3 - Universidade do Amazonas, Manaus, AM, Brazil. E-mail: elena@argo.com.br, elena@tecnonet.it 
Formation and the granitic rocks of the Guaporé shield. The Pacaás Novos Range is composed of arkosic sandstones and conglomerates about 400 meters thick of the Pacaás Novos Formation, of Precambrian age (Radambrasil 1978) and the maximum heights reach 900-m a.s.l. The range is a testimony of a broad and old eroded synclinal with an approximately E-W axis. The abrupt northern flank was related to compressive neotectonic activity, which produced faulting in a NW-SE direction and a W-E secondary set of fractures (Scandolara 1999). The sedimentary rocks have low dip, reaching a maximum of $40^{\circ}$ (Radambrasil 1978). Detailed studies on the western end of the Pacaás Novos Range, near the city of Guajara Mirim were undertaken (Fig. 3). In this area the range appears as a set of isolated blocks, elongated in the N-S direction and with a northern flank controlled by an E-W lineament. Dip measurements in the strata and fractures are presented on figure 4 . The beds dip gently and predominantly to the south. The blocks show a conspicuous asymmetry with an abrupt northern flank and a gentler southern flank. The maximum heights are 362-m a.s.1.

THE PIEDMONT AREA In the northern piedmont there is contact between the range escarpment formed by the sedimentary rocks of the Pacaás Novos Formation and the granitic rocks of the Guaporé Shield. The rocks of the shield are strongly weathered, forming
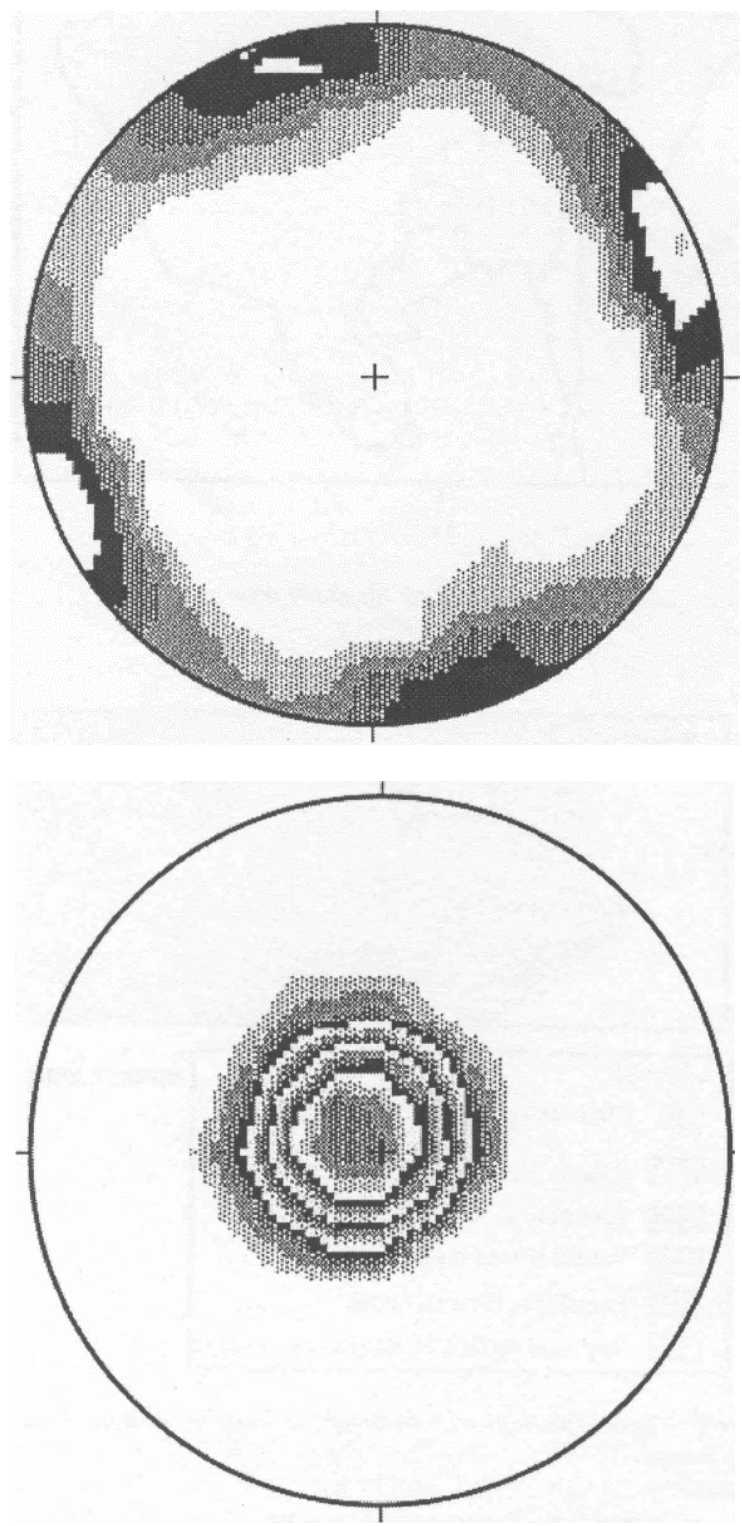

Figure 3 - a - Fracture strike measurements, $b$ - Strata dip measurements. Method of Kamb (1959). saprolite. Residual weathered blocks of granite can be found inside the saprolite mass. The thickness of the saprolite mantle is unknown because the deep base is not apparent in the outcrops.

On the northern flank of the range, the horizontal to sub-horizontal strata of the Pacaás Novos Range form an abrupt front $150 \mathrm{~m}$ in height on the piedmont level, with a free face of 70-80 m. On the foot slope of this free face are found thick and coalescing talus of detritus. Talus thickness is variable, reaching up to $75 \mathrm{~m}$, the slope reaches $34^{\circ}$. The talus is continuously present along the piedmont area; its base is in relation with the smoothly dissected pediment surface that extends on large parts of the northern piedmont (Fig. 3). The pediment developed on the weathered granitic rocks of the Guapore Shield. The pediment surface is very gentle, with angles of $5^{\circ}$ in the proximal area, decreasing to 1 away from the range. In some sectors of the piedmont, numerous outcrops can be found of the saprolite on which the pediment developed. Also granitic blocks and tors are frequent, randomly scattered.

The in transit alluvium on the pediment surface is very thin, no more than $40 \mathrm{~cm}$ thick, and formed by conglomerate with gravels of variable size. The best-rounded gravels were reworked from the conglomerates of the Pacaás Novos Formation. However, an angular population of quartz pebbles comes from the residual products of the saprolite. The thin alluvial in transit sediments of the pediment suffered lateritization, which resulted in duricrust formation during a sub-humid climate (Fig. 5). The conglomerate on the pediment was eroded and is present as a dismantled ferricrete or duricrust. This crust was dissected and for this reason is discontinuous, forming isolated accumulations of blocks on the pediment surface.

The installation of a drainage network on the pediment surface produced dissection. Alluvial and colluvial sediments were deposited in the valleys. This alluvial/colluvial unit is formed principally by gray to brown fine sediments, with some ochre tones and mottling by lateritization. The unit is situated on a lower level than the pediment and, in general, has higher declivity. We could not determine in the outcrops the total thickness of the sediments. However we found in a gully a 2.6-m thick profile composed of silty sandy sediments, brown gray, highly bioturbated, porous, forming vertical banks. Occasionally were recorded cross stratification in sandy sediments and lamination in finer sediments. Lenses of gravel formed by quartz particles, $5-20 \mathrm{~cm}$ in maximum thickness are found sporadically. In general, piping develops gullies. In the western end of the northern piedmont the unit is formed by alluvial fans that cut the detrital talus and the pediment. The fan slopes are up to $10^{0}$ in the apex area and $3^{0}$ in the middle/distal area. The most important fan lobes are found in the first 50-m from the piedmont angle. The coarsest sediments (blocks and boulders) form them. Thermoluminescence dating was performed on fan sediments in the laboratories of the University of Peking, China, indicating an

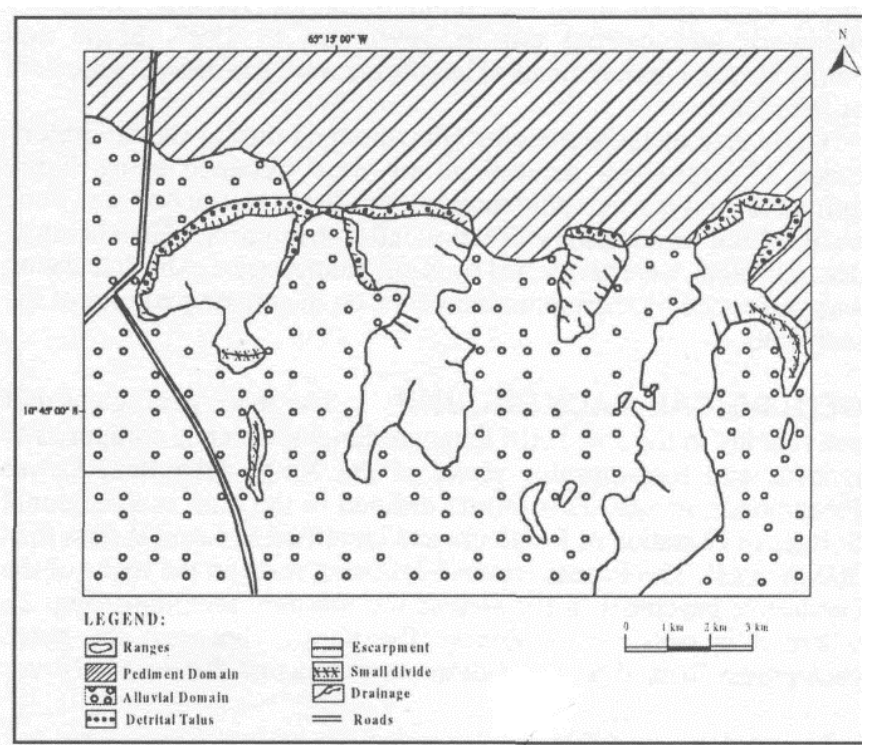

Figure 4 - Main geomorphological domains in. the Pacaás Novos Range, close to Guajará Mirim. 

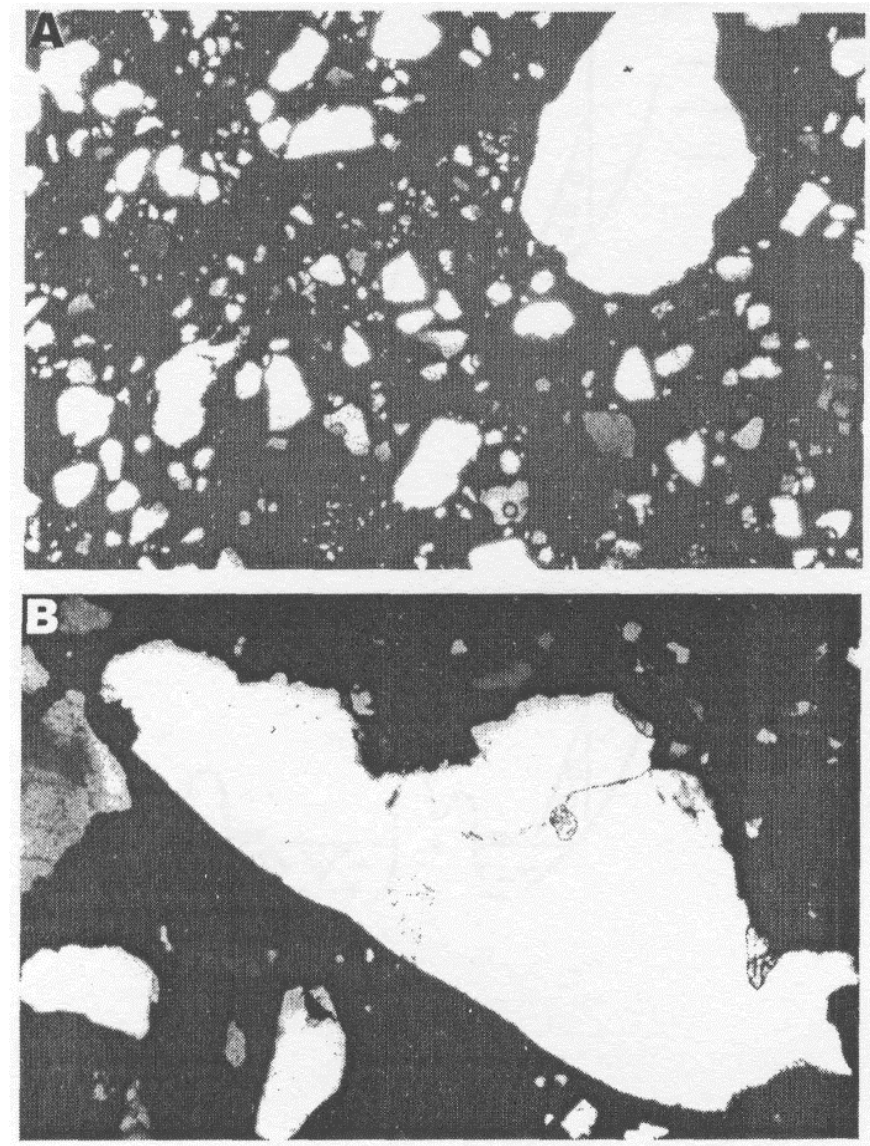

Figure 5 - Thin section showing the composition of the ferruginous duricrust developed on the pediment surface, a) Clast heterogranularity with iron oxide cement. Dimension: $3.0 \times 2.0 \mathrm{~mm}$. X Nicols b) quartz particles corroded by iron oxide cement. Dimension: $1.2 \times 0.8 \mathrm{~mm}$, X nicols

Upper Holocene age for these deposits. The ages obtained were 1.58 +/- 0.2 ka BP (sample ST 120) e 2.88 +/- 0.4 (sample ST 121). The samples were collected on the western end of the northern piedmont of the Pacaás Novos range $\left(10^{\circ} 43.332 \mathrm{~S}\right.$ and $\left.65^{\circ} 016.368 \mathrm{~W}\right)$. At present this unit is being eroded by the reactivation of the drainage network. The southern flank of the range is gentler and the drainage network is better hierarchized than on the northern flank. The creeks have a torrential dynamics. The longitudinal profile of the watercourses is frequently broken by the presence of hard levels in the sedimentary rocks. In the southern piedmont there is aggradation, with a strong and rapid grain size selection of the sediments. The alluvial/colluvial domain is the more important geomorphological unit on the southern piedmont (Fig, 3).

ANALYTICAL RESULTS: THE REGIONAL SURFACE OF PLANATION, LEVEL II Mineralogical and geochemical analysis were performed to determine the type and intensity of chemical weathering on the granitic rocks of the Regional Surface of Planation, Level II. The pediment domain developed on that regional surface.

This surface extends on the western and northwestern part of the state of Rondonia and was developed mainly on Precambrian rocks. At present it is partially covered by undifferentiated Neogene deposits. Its surface, less than $300 \mathrm{~m}$ a. s. 1 . in height shows a relatively flat landscape with the presence of inselbergs, tors, and half orange-like hills..Nevertheless there are no systematic data on the thickness of the weathering mantle; it was possible to observe in some points a thickness of $10-20 \mathrm{~m}$. Geochemical analyses were performed on saprolite, on fresh granite and on weathered blocks of granite in the northern piedmont of the Pacaás Novos Range (pediment domain)

The pediment domain of the Pacaás Novos Range can be considered part of the Regional Surface of Planation, Level II that is widespread on the western and northwestern corners of Rondonia (Fig. 2).
Table 1 - Chemical composition determined by X ray fluorescence on the total fraction of the samples

\begin{tabular}{|l|r|r|r|}
\hline \multicolumn{1}{|c|}{$\begin{array}{c}\text { Oxides } \\
\%\end{array}$} & Saprolite & $\begin{array}{c}\text { Residual } \\
\text { block in the } \\
\text { saprolite }\end{array}$ & \multicolumn{1}{c|}{$\begin{array}{c}\text { Fresh } \\
\text { granite }\end{array}$} \\
\hline $\mathrm{SiO}_{2}$ & 49.39 & 53.25 & 73.57 \\
$\mathrm{TiO}_{2}$ & 0.52 & 0.47 & 0.26 \\
$\mathrm{Al}_{2} \mathrm{Fe}_{3}$ & 32.34 & 26.65 & 13.12 \\
$\mathrm{Fe}_{2} \mathrm{O}_{3}$ tot. & 4.79 & 9.86 & 2.19 \\
$\mathrm{MnO}$ & 0.08 & 0.09 & 0.09 \\
$\mathrm{MgO}$ & 0.26 & 0.26 & 0.54 \\
$\mathrm{CaO}$ & 0.01 & 0.01 & 0.96 \\
$\mathrm{Na}_{2} \mathrm{O}$ & 0.00 & 0.02 & 3.66 \\
$\mathrm{~K}_{2} \mathrm{O}$ & 0.36 & 0.21 & 4.69 \\
$\mathrm{P}_{2} \mathrm{O}_{5}$ & 0.06 & 0.05 & 0.09 \\
L.O.I. & 12.18 & 9.13 & 0.83 \\
\hline
\end{tabular}

Table 2 - Mineralogical qualitative or semi-quantitative composition of saprolite and residual granitic block immersed in the saprolite, determined by $X$-ray diffraction D - Dominant; I = Important; $S$ - Scarce; $T$ - Trace

\begin{tabular}{|c|c|c|c|c|c|c|c|}
\hline Unit & Quartz & Feldspar & III/Mi & Kaol & $\begin{array}{c}\text { Chlorit } \\
\text { e }\end{array}$ & Gibbsite & $\begin{array}{c}\text { Hemat- } \\
\text { Goeth }\end{array}$ \\
\hline Saprolite & D & S & T & S & - & I & S \\
\hline $\begin{array}{l}\text { Residual } \\
\text { block }\end{array}$ & I & T & S & S & T & S & S \\
\hline
\end{tabular}

Table 1 shows results of chemical analyses of samples of the saprolite, of the residual weathered granitic blocks immersed in the saprolite, and of fresh granite.

The results indicate the progressive evolution of chemical weathering on granitic rocks. As shown, the progressive decreasing of $\mathrm{SiO}_{2}$ is proportional to the increase of $\mathrm{Al}_{2} \mathrm{O}_{3}$, which is an important component of kaolinite and gibbsite (Table 2). $\mathrm{Al}$ (X from the saprolite is in large part used in the composition or the kaolinite and considerable part of $\mathrm{Si}_{2} \mathrm{O}$ is also used in kaolinite formation.

The alkaline original compounds of feldspar $\left(\mathrm{Na}_{2} \mathrm{O}\right.$ and $\left.\mathrm{K}_{2} \mathrm{O}\right)$ are quickly leached, and thus missing in the saprolite, or carried away by water. The total $\mathrm{Fe}_{2} \mathrm{O}_{3}$ increases in the saprolite in a variable manner.

The complexity of deposits and landforms that compose the Regional Surface of Planation, Level II, suggests the participation of etchplanation processes in its genesis. The presence of pediments, surface sedimentary deposits, a deep weathering mantle, tors, inselbergs, laterites, half orange-like hills, indicate a polygenetic origin for this unit, supporting the hypothesis of etch-planation process during the elaboration of the surface, comprising considerable geological time for its evolution.

DISCUSSION Traditionally the Amazonian landscape has been described from a static point of view, accepting that minor and not drastic changes in its morphodynamics happened along the Quaternary. However, the geomorphological data of the Pacaás Novos region show strong evidence that the morphogenetic systems in Western Amazonia changed during the Quaternary.

Our evolutionary scheme starts with the development of the thick saprolite on the unaltered rocks of the Guapore Shield (Fig. 6a). The formation of coalescent detrital talus along the northern piedmont and the pediment indicates climatic deterioration in this region. The climate was markedly more arid than the present one, permitting the development of the widespread erosional surface (Fig. 6b).

Afterward, the in transit alluvium on the pediment was laterized, forming a duricrust on the pediment surface. The morphogenetic episode can be related to sub-humid conditions (Fig. 6c).

A new climatic change is recorded at the time a drainage network dissected the pediment surface, dismantling the ferruginous crust (Fig. $6 d)$. The alluvial fans and the alluvial/colluvial sediments were deposited by sheet wash and creeks during more arid conditions than the present (semiarid?) (Fig. 6e). At present, rainforest covers the landscape and mask these landforms. The scarcely developed present day drainage network might be in an incipient state of vertical incision (Fig. 6f). 

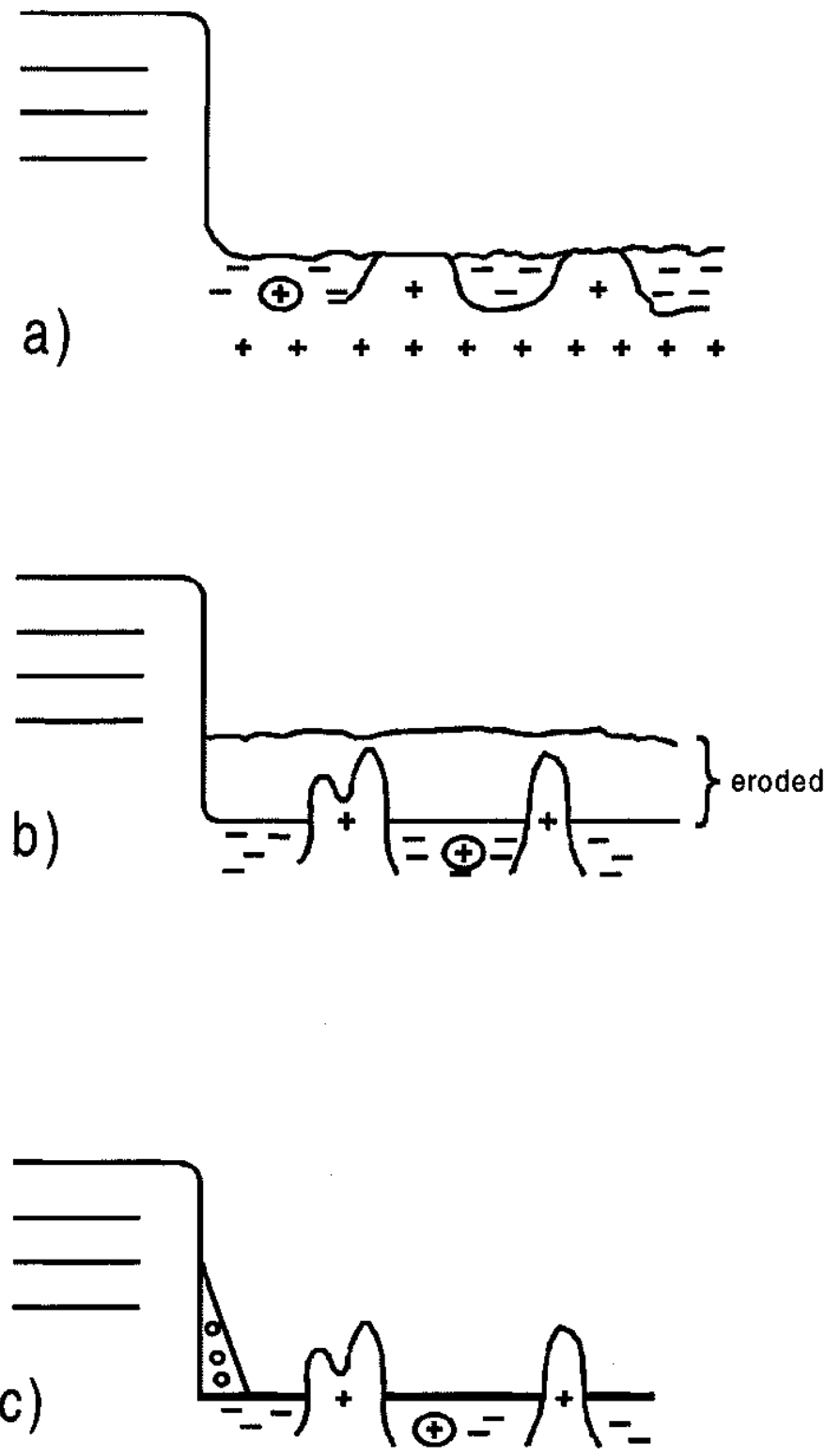

Figure 6-Evolutive geomorphological sequence in the Pacaás Novos area.

CONCLUSION The geomorphologic data of the Pacaás Novos presented here are unequivocal evidences of climatic changes in this part of Amazonia during the Quaternary.

However we do not have a good chronology of the morphogenetic episodes that can permit us to correlate them to the Quaternary general climatic changes.

The complex geomorphological sequence in the Pacaás Novos Range permits us to claim that it is necessary and possible to find new

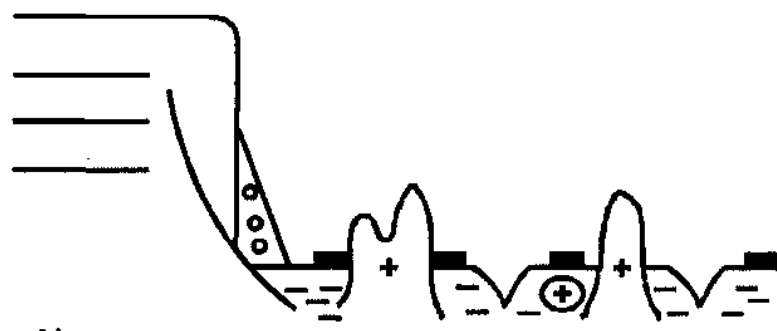

d)
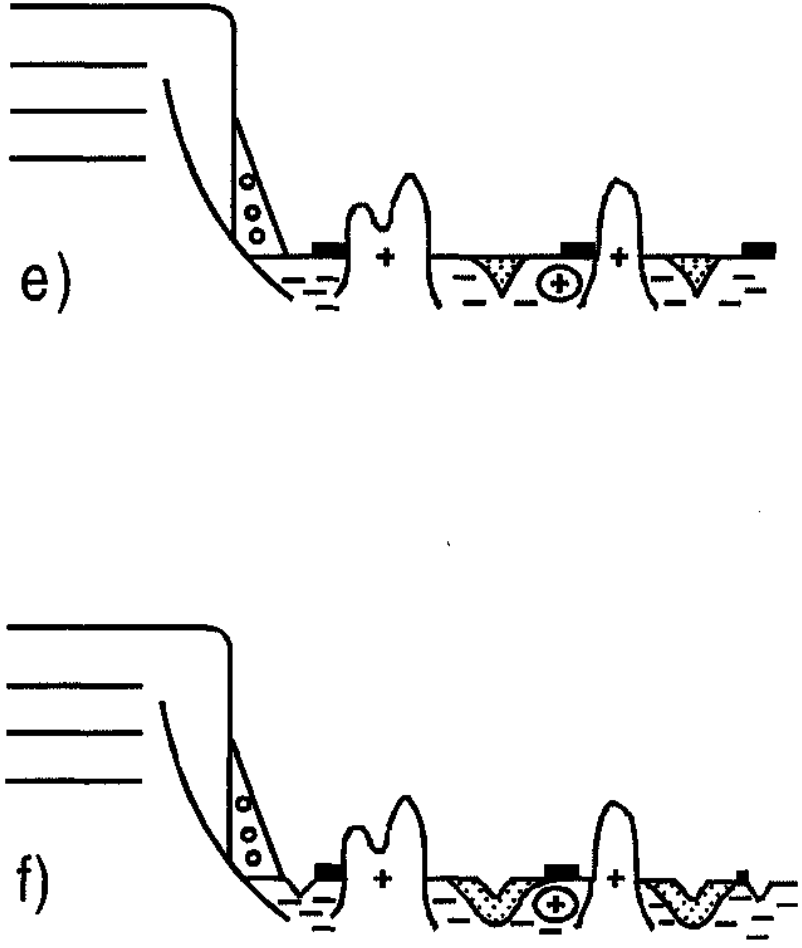

\section{References}

Ab' Saber A.N.I967.Problemas Geomorfologicos da Amazonia Brasileira. Atas do Simposio sobre biota Amazdnica, 1:35-68.

Ab'Saber A.N.1982. The paleoclimate and paleocology of Brazilian Amazonia. In: G.T.Prance (ed),Biological Diversification in the Tropics. New York, Columbia,. 159 ,

Absy M.L., Cleef A., Fournier M., Martin L, Servant M., Siffedine A., Ferreira da Silva M. Soubies E, Suguio K., Tura B., Van der Hammen T. 1991 Mise en evidence de quatre 60000 dernieres annes. Premiere comparaison avec d'autres regions tropicales. 60000 dernieres annes. Premiere comparaison avec d'autres regions tropi

Costa M.L. 1991. Aspectos geologicos dos lateritos da Amazonia. Revista. Brasileira de. Geocencias., 21:154-160

Chauvel, A., Lucas, Y, and Boulet, R, 1987 On the genesis of the soil mantle of the region of Manaus. Central Amazonia, Brazil. Experientia, 43:234-241. kinds of paleoenvironmental and paleoclimatic indicators in Amazonia, that permit to go back to some periods of the Quaternary which are almost totally unknown to us, as happens with a large part of the Pleistocene. Thus, the geomorphological research becomes a need to reconstruct the past, as currently demonstrated by results of different authors in other tropical rainforest of the world. As exemplified in this paper, the ways indicated by early research pioneers in Amazonia, and successively forgotten, need to be retaken.

De Ploey 1964 Cartographic geomorphologique et morphogese aux environs du StanleyPool (Congo). Acta Geogr. Lovaniensia 3:431-441.

Iriondo M. 1982. Geomorfologia da Planicie Amazônica.. In: SBG. Atas do Simpósio do Ouaternário do Brasil 323-348.

Iriondo M \& Latrubesse E1994. A probable Scenario for a dry Climate in Central Amazônia during the Late Quaternary. Quaternary International 21:121-128

Journaux. M.A. 1975. Gemorphologie des bordures de L'Amazonie Bresilienne: le modele versants: essai d'evolution paléoclimatique. Bulletin, Association Geographie de la

KambW.B.. 1959. Petrofabric observations fom Blue Glacies, Washington, in relation to theory and experiment. Jouranl. Geophys. Research., 64:1908-1909.

Kadomura H. \& Hori N. 1990 Environmental implications of slope deposits in humid tropical Africa:evidence from southern Cameroon and Western Kenya Geographical Reports, Tokyo Metropolitan University, 25:213-236. 
Klammer G. 1971 Uber plio-pleistozane Terrasen und ihre sediment im uteren Amazonasgebiet. Geomorph., N.F. 15:62-106.

Klammer G. 1984 The relief of the extra-Andean Amazon basin. In: H.Scioli (ed) The Amazon..Dordrecht Dr. W. Junk Publishers, 47-84

Latrubesse E. \& Franzinelli E. 1998. Late Quaternary Alluvial Sedimentation in the Upper Rio Negro Basin,Amazônia, Brazil: Palaeohydrological Implications. In: Behito G., Baker V., Gregory K. (eds.) Paleohydrology and Environmental Change, London, John Wiley \& Sons Ltd., 259-271.

Latrubesse E. \& Ramonell C. 1994 A Climatic Model for Southwestern Amazonia at Last Glacial times. Quaternary International. 21:163-169

Latrubesse E. \& Rancy A. 1998 The Late Quaternary of the Upper Jurua River, Southwestern Amazonia, Brazil: geology and vertebrate paleontology. Quaternary of South America andAntartic Peninsula, 11, $27-46$.

Lucas Y, Boulet R., Chauvel A., Veillon L. 1987. Systemes ferralitiques-podzols en region amazonienne. In .D. Righi \& A. Chauvel Podzols and Podzolisation (eds), Comptes Rendus de la Table Ronde International, 1986, Association Franfaise, pour 1' Etude du Sol, INRA/ORSTOM, Poitiers. 53-65

Lucas Y, Boulet R., Chauvel A. 1988 Intervention simultanee des phénoménes d' enforcement vertical et trasformation laterale dans la mise en place de systemes sols ferrallitiques-podzols de 1'a Amazonie Bresilienne $C R$. Academie des Sciences Paris, Serie II, 306:1395-1400.

Meis M.R.M. 1968. Consideracoes geomorfologicas sobre o Medio Amazonas. Revista Brasileira de Geografia, 30:3-20.

Merles L., Dunne T, Martinelli L. 1996. Channel-floodplain geomorphology along the SolimõesAmazon river, Brazil. GSA Bulletin, 108:1089-1107

Nimer E. 1989. Climatologia do Brasil. Rio de Janeiro, IBGE, 421 p.

Nimer E. 1989. Climatologia do Brasil. Rio de Janeiro, IBGE, $421 \mathrm{p}$.
Rancy A 1993. Western Amazon Paleomammals and the forest refugia model. In: Franzinelli E, Latrubesse E (eds): International Symposium on the Quaternary of Amazonia, Abstracts and Sci. Contr. Manaus,. UFAM, 45-48

Rasanen M., Neller R., Salo J., Jungens H. 1992. Recent and ancient fluvial deposition system in the Amazonian foreland basin Peru. Geol. Mag., 129:293-306
RADAMBRASIL 1978. Folha SC20-Porto Velho, Projeto Radambrasil, Rio de Janeiro, DNPM

Runge J. 1992. Geomorphological observations concerning palaeoenvironmental conditions in caster Zaire. Z. Geomorph. N.F. Suppl.. 91:109-122.

Runge J. 1995. New results on Late Quaternary landscape and vegetation dynamics in eastern Zaire (central Africa). Z. Geomorph. N.F. Suppl.Bd. 99:65-74

Scandolara J. 1999. A neotectonica de Rondônia e adjacencias: esboço preliminar e aspectos evolutivos. SBG Nucleo None VI Simp. GeoLAm. Bol. Resumos Exp., 255-258,

Thomas M.F. 1994. Geomorphology in the tropics. A study of weathering and denudation in low latituds. J. Wiley \& Sons, $460 \mathrm{p}$.

Thomas M.F. \& Thorp M.B. 1985 Environmental change and episodic etchplanation in the humid tropics of Sierra Leone: the Koidu etchplain. In I. Douglas \& T. Spencer (eds) Environmental Change and Tropical Geomorphology),. London.Alien and Environmental
Unwin, 239-267

Thomas M.F. \& Thorp M.B. 1992 Landscape dynamics and surface deposits arising from late Quaternary fluctuations in the forest-savanna boundary. In P. A. Furley J. \& Proctor J.A Ratter (eds) Nature and dynamics of Forest-Sabanna Boundaries., London. Chapman \&Hall, 215-253.

Tricart J. 1977 Types des lits fluvieux en Ämazonie bresilienne. Annais de Geographic, 473:1-54

Tricart J. 1985 Evidences of Upper Pleistocene dry climates in northern South America. In I. Douglas \& T. Spencer (eds.) Environmental Change and Tropical Geomorphology, London, Alien and Uwin., 197-217

van der Hammen T. \& Absy M.L. 1994. Amazonia during the Last Glacial. Palaeogeography, Palaeoclimatology.Palaeoecology, 109:247-261

Contribution IGC-033

Received January 28, 2000

Accepted for publication May 22,2000 